INTERNATIONAL JOURNAL OF MULTIDISCIPLINARY RESEARCH AND ANALYSis

ISSN(print): 2643-9840, ISSN(online): 2643-9875

Volume 04 Issue 06 June 2021

DOI: 10.47191/ijmra/v4-i6-07, Impact Factor: 6.072

Page No.- 726-731

\title{
The Relationship between Stock Market Development and the Performance of the Nigerian Economy
}

\author{
Ilugbusi Bamidele Segun $(\mathrm{PhD})^{1}$, Atayi Abraham Vincent ${ }^{2}$, Ayeni Tonia Yetunde $(\mathrm{PhD})^{3}$, Akanmu \\ Ayodeji Abiola ${ }^{4}$ \\ ${ }^{1}$ Department of Management and Entrepreneurship, Afe Babalola University, Ado Ekiti, Ekiti State, Nigeria \\ ${ }^{2}$ Department of Economics, Afe Babalola University, Ado Ekiti, Ekiti State, Nigeria \\ ${ }^{3}$ Department of Banking and Finance, Afe Babalola University, Ado Ekiti, Ekiti State, Nigeria \\ ${ }^{4}$ Department of Economics, Afe Babalola University, Ado Ekiti, Ekiti State, Nigeria
}

\begin{abstract}
This paper examined the relationship between stock market development and performance of the Nigerian economy. The analysis scope covered a period of 10 years spanning from 2010-2020. The analytic procedure for the information was econometric. The estimation techniques used are co-integration, Granger Causality and Error Correction to check whether the exchange indices have impacted on the macroeconomic performance of Nigeria. The result showed that the constant parameter is negatively or inversely associated with LGDP. The coefficient of the constant parameter (B0) is -15038.18 . This suggests that if all the explanatory variables are held constant, LGDP which is that the explained variable will increase by 15038.18 units. Conclusively, all variables might not have been reasons enough for a change in the Gross domestic product level, but the fact still remains that there is an affinity between them. The study recommends that the central bank of Nigeria (CBN) being the monetary authority should plan and implement policies that bring about an increase flow of investment funds and improves the extent of capitalisation to the economy.
\end{abstract}

KEYWORDS: Stock Market, Performance, Nigerian Economy, Exchange Commission

\section{INTRODUCTION}

Over time, the Nigerian stock exchange market has grown. The effects of this development, however, does not appear to have had a significant impact on the Nigerian economy. The securities market has been recognized as an institution that contributes to emerging and industrialized economies' socioeconomic progress and development. According to Ogboi and Oladipo (2012), studies on this subject suggest that the current exchange is the most exciting and hopeful sign of a country's economic activity. However, the consequences have no obvious direction. It has been discovered that there is a rising body of issues and disputes regarding the function of stock markets in economic process and development (Sulaiman \& Mohammed, 2014), which is why study on this topic continues to attract interest and attention. Various empirical research reveal that exchange rate development is significantly connected with actual per capita growth rates (Rousseau \&Wachtel, 2000; Beck \& Levine, 2003). The effect of the securities market on economic processes was also investigated by Ekundayo (2002) and Osaze (2000), with conflicting results. Donwa and Odia (2010), for example, found that exchange indices have little effect on the Gross Domestic Product. Within Nigeria, the securities market provides the necessary lubricant to keep the economy running.

The bond market and the stock exchange are two components of the securities market, both of which signal the market's overall success. In addition, the stock exchange gives investors a hint as to what steps they should take in the future. According to Bernardo (2005), the Nigerian stock exchange remains low and unliquid. Actions to improve stock exchange liquidity have had mixed outcomes, with one problem being the Nigerian exchange's lack of depth. The most recent literatures on the Nigerian securities market, notably the exchange, have recognized the market's phenomenal performance in recent years. The critical significance of securities market development in the performance of the Nigerian economy, on the other hand, has not been empirically explored, leaving a significant void in this field. As a result, the purpose of this research is to see how the growth of the securities market has influenced the performance of the Nigerian economy. 


\section{The Relationship between Stock Market Development and the Performance of the Nigerian Economy}

\section{LITERATURE REVIEW}

The stock exchange is frequently described as a place for raising medium to long-term capital. The market is a place where future loanable monies can be traded, lent, and borrowed. Mbat (2001) defined it as a forum through which surplus monies are made available to deficit economic units in the future. It should be noted, however, that while all surplus economic units have access to the securities market, not all deficit economic units have the same ease of access. The Nigerian securities market is one of the constituents of the Nigerian securities market, which is governed by the stock exchange.

The Nigerian Securities and Exchange Commission (NSEC) is the top body in charge of overseeing and regulating the country's securities industry. The commission was founded in 1979 by the safety and exchange commission decree, and it began operations on April 1, 1978. Prior to the SEC, two entities were responsible for supervising securities market activity in Nigeria, one after the other. The most important was the Capital Issues Committee, which ran from 1962 to 1972 . Even while its functions included the coordination of securities market activity, it couldn't be seen because its functions were more or less advisory without the force of instruction. The Capital Market Issues Commission (CIC), which was established in March 1973, was the next agency to be established. Unlike its predecessor, the C.I.C. had complete control over the value, timing, and volume of securities to be issued. Despite its expanded coverage, the CIC went unnoticed since the apex capital market was only concerned with public enterprises, and its activities did not include the stock market or government securities.

\section{Theoretical Literature}

The Efficient Market Hypothesis (EMH), developed by Fama in 1965 and used by Ewah, Sang, and Bassey (2009), states that financial markets are efficient or that the costs on traded assets have already reflected all known information about the market, and thus are unbiased because they represent the collective beliefs of all investors about the capital market's future prospects.

Rose's (1976) financial theory, which Ossisanwo and Atanda (2012) applied, claims that the only way to link macroeconomic variables and stock exchange returns is through arbitrage pricing (APT), which allows various risk factors to explain asset returns. While the first empirical works on APT focused on individual security returns, it will also be applied in an aggregate exchange context, where a change in a particular macroeconomic indicator could be interpreted as reflecting a change in an underlying systemic risk factor influencing future returns. Recent empirical studies that used APT theory to link the state of the macro-economy to stock exchange returns, such as Ossisanwo and Atanda (2012), are characterized by modeling a brief run relationship between macroeconomic variables and thus the stock price in terms of first difference, assuming trend stationarity. This theory implies that it is commonly used to target the long-term link between the exchange rate and broad finances, which is one of the most important macroeconomic factors.

In the absence of a positive microeconomic theory that manages the risk associated in the market, Capital Asset Pricing Theory predicts the behavior of the capital market. The idea is that cyclical fluctuations are caused by deviations of the guaranteed rate of growth from the natural rate (that is, from the speed of growth cherish the speed of growth of the population); deviations of the guaranteed rate of growth from the natural rate (that is, from the speed of growth cherish the speed of growth cherish the speed of growth cherish the speed of growth cherish the speed of growth cherish the speed of growth cherish the speed of growth cherish the speed of growth cherish the speed of growth cherish the speed of growth cherish the speed of growth cherish (Ross, 1976).

\section{Review of Related Empirical Literature}

Ramin, Lee, and Mohammed (2004) investigated the long-term equilibrium relationships between selected macroeconomic variables and the Singapore securities market index (STI), as well as various Singapore Exchange Sector indicesthe finance index, the property index, and thus the hote index-in Singapore. The study shows that changes in short and longterm interest rates, industrial production, pricing levels, charge per unit, and finances have a cointegrating link with Singapore's stock market and property index.

In the Russian market, Mauri (2006) uses multivariate analysis to see how effectively APT describes the Russian 20 largest stocks on various macroeconomic variables. Except for one equity, which was significant to expected price movements, the results demonstrate no meaningful association between equities returns and macroeconomic variables. However, this does not rule out the possibility that the APT does not function with asset pricing in Russia, and the problem could be inherent in the concept due to the lack of lagged macroeconomic variables. Sulaiman, Adnan, and Adnan (2009) investigated the relationship between macroeconomic variables and KSE (Karachi Stock Exchange) share prices in the setting of Pakistan. The research takes into account a variety of macroeconomic factors such as the exchange rate, interchange rate, industrial production index (IPI), whole sale index (WPI), gross fixed capital formation (GFCF), and wide money M2. These variables were calculated using data from 1986 to 2008. The findings reveal that following their formation in 1991, the exchange rate and interchange reserve have a large impact on stock 


\section{The Relationship between Stock Market Development and the Performance of the Nigerian Economy}

prices, whereas other variables such as IPI and GFCF have a minor impact. The findings also revealed that internal factors such as increased production and capital formation are inconsequential, however external factors such as $\mathrm{M} 2$ and interchange have a beneficial impact.

Yui (2008) examines the Efficient Market Hypothesis (EMH) in the context of monetary policy in the Chinese securities market. VAR models are commonly used to estimate the relationships between stock returns and relative macroeconomic factors connected with monetary policy. The estimated vector auto-regression (VAR) computation shows that lagged changes in charge per unit, cash in hand, and GDP have a significant impact on stock returns. The results reveal that the efficient market hypothesis $(\mathrm{EMH})$ of China exchange has a partly strong variation..

Abdul (2008) uses co-integration and Granger causality tests that are resilient to structural breaks to analyze the dynamic interactions between four macroeconomic factors and stock prices in Pakistan. The findings strongly show that stock prices and macroeconomic factors such as consumer prices, industrial production, rate, and hence the market rate of interest are cointegrated. With the exception of consumer prices, which exclusively affect stock prices, estimates of bivariate error-correction models suggest that there is a long run bidirectional causality between stock prices and macroeconomic variables. The findings also suggest that stock prices and Granger are influenced by interest rate changes in the short run. The methodology, on the other hand, is unable to investigate any short-run causality between stock prices and the remaining three macroeconomic variables. As a result, it will be argued that the link between the stock exchange's health, as measured by rising share prices, and the economy's health is merely a long-term occurrence.

Soyode (2009) attempted to investigate the relationship between stock prices and macroeconomic variables such as cost per unit, inflation, and cost per unit. He discovered that macroeconomic variables are intertwined with stock prices and, as a result, are linked to stock returns.

\section{METHODOLOGY}

Annual Statements of Accounts, Key Financial and Economic Indicators, Security and Exchange Commission market bulletins and pertinent journals, Nigerian exchange fact books, financial institution of Nigeria Statistical Bulletin, and Nigerian stock market publications were utilized to compile the data. The standardized ordinary least square (OLS) analytical methodology was used in the study. The information is analyzed using an econometric technique. To see if the stock exchange indexes have had an impact on Nigeria's macroeconomic performance, estimating techniques such as co-integration, Granger Causality, and Error Correction were employed.

\section{Specification of the Model}

GDP $=f(M C A P, F D I, I N F, I T R)$

LnGDP $=\alpha 0+\alpha 1$ LnMCAP $+\alpha 2$ LnFDI $+\alpha 3$ LnINF+ $\alpha 4$ LnITR $+u$

Where:

The apriori expectation is $\alpha 1, \alpha 2, \alpha 3, \alpha 4>0$

LnGDP = Gross Domestic Product

LnMCAP $=\quad$ Market Capitalization

LnFDI = Foreign Direct Investment

LnINF = Inflation

LnITR = interest rate

$\mathrm{u}=\quad$ Disturbance Term

$\alpha \quad=\quad$ Intercept

$\alpha 1-\alpha 4=\quad$ Coefficient of the Independent Variables.

Note, all variables are in their natural logarithm form.

4. RESULTS AND INTERPRETATION

Table 1: OLS Results Summary

\begin{tabular}{|l|l|l|l|l|l|l|l|l|l|}
\hline $\begin{array}{l}\text { Dependent } \\
\text { Variable }\end{array}$ & \multicolumn{3}{|l|}{ Independent Variables } & \multicolumn{3}{c|}{ Summary of Results } \\
\hline LGDP & Constant & LMCAP & LFDI & LINFR & LINTR & $\mathrm{R}^{2}$ & Adj. R $^{2}$ & F-Cal & DW-Stat \\
\cline { 2 - 9 } & -15038.18 & 3.331035 & 0.000117 & 20.77884 & 546.5605 & 0.888 & 0.86938 & 47.5917 & 0.835870 \\
& $(9779.488)$ & $(0.65509$ & $(8.14 \mathrm{E}-$ & $(106.722$ & $(393.5316$ & 042 & 3 & 0 & \\
& & $6)$ & $05)$ & $1)$ & ) & & & & \\
\hline
\end{tabular}

Source: Author (2021). 
The Relationship between Stock Market Development and the Performance of the Nigerian Economy

From the results of the OLS above, the constant parameter is inversely associated with LGDP. The coefficient of the constant parameter (BO) is -15038.18 . this suggests that if all the explanatory variables are held constant, LGDP which is the explained variable will increase by 15038.18 units. The coefficient of market capitalisation (LMCAP) is 3.331035. This signifies that the short run, market capitalisation (LMCAP) is directly associated with LGDP. The implication can be a unit increase in LMCAP, which implies LGDP will increase by 3.331035 units. Also, the coefficient of foreign direct investment (LFDI) is 0.000117 and it means a causal relationship exist between LGDP and LFDI within the short run. The short run equilibrium relationship existing between LGDP and LFDI is in conformity with the a priori expectation.

The link reveals that an increase in LFDI will cause LGDP to rise by 0.000117 units. The coefficient of rate (LINFR) is 20.77884, this implies that a positive relationship exists between LGDP and LINF and this relationship is against the a priori expectation. LGDP will increase by 20.77884 units, if the speed increases by a unit. Also, the coefficient of charge per unit (LINTR) is 546.56. This shows that LINTR is positively related to LGDP and this relationship is in line with the stated a priori expectation. A unit increase within the ratio of LINTR to LGDP i.e., LINTR will consequently end in LGDP increasing by 546.5605 units. The coefficient of multiple determination represented as R2 with a price of $0.888042 \approx 0.89$ shows that $89 \%$ of total difference in LGDP could also be explained by LMCAP, LFDI, LINFR, and LINTR while the remaining $11 \%$ is explained by the error term not within the model. The adjusted R2 of $0.869383 \approx 87 \%$ further confirms the goodness fit of the model.

Table 2: Johansen Co-integration Result

\begin{tabular}{|l|l|l|l|}
\hline E. Value & Trace Statistic & 5\% C. value & No. of CE(s) \\
\hline .777182 & 90.89942 & 69.81889 & None ${ }^{*}$ \\
\hline 0.552610 & 50.36160 & 47.85613 & At most $1^{*}$ \\
\hline 0.407638 & 28.64484 & 29.79707 & At most 2 \\
\hline 0.335887 & 14.50661 & 15.49471 & At most 3 \\
\hline 0.120129 & 3.455448 & 69.81889 & At most 4 \\
\hline
\end{tabular}

Source: Author (2021).

\section{Trace test indicates 2 co-integrating equation(s) at the 0.05 level}

* Denotes rejection of the hypothesis at the 0.05 critical level

Based on the above table, it may be confirmed that a causal long-run co-integration exists between (LGDP), capitalization (LMCAP), Foreign direct investment (LFDI), rate of inflation (LINFR), and rate of interest (LINTR). This is often because the critical value at $5 \%$ is a smaller amount than the trace statistic at 0 in row 1 and a couple of cointegration equations. Based on this, the hypothesis shows no co-integration has been rejected at $5 \%$ level of significance.

Table 3: Over-Parameterized Model (ECM1) results

\begin{tabular}{|l|l|l|l|l|}
\hline Models & Co-efficient & STD Error & T. Statistics & P. Value \\
\hline $\mathrm{D}(\mathrm{GDP}(-1), 2)$ & -0.624596 & 0.153365 & -4.072609 & 0.0010 \\
\hline $\mathrm{C}$ & 105.9925 & 954.9735 & 0.110990 & 0.9131 \\
\hline $\mathrm{D}(\mathrm{MCAP}, 2)$ & 1.212129 & 0.366139 & 3.310575 & 0.0048 \\
\hline $\mathrm{D}(\mathrm{MCAP}(-1), 2)$ & 0.925216 & 0.369970 & 2.500786 & 0.0245 \\
\hline $\mathrm{D}(\mathrm{FDI}, 2)$ & 0.000284 & 0.000127 & 2.229430 & 0.0415 \\
\hline $\mathrm{D}($ FDI(-1),2) & 0.000402 & 0.000134 & 3.008442 & 0.0088 \\
\hline $\mathrm{D}($ INFR,2) & 26.40018 & 47.94506 & 0.550634 & 0.5900 \\
\hline $\mathrm{D}($ INFR(-1),2) & 7.669975 & 44.74439 & 0.171418 & 0.8662 \\
\hline $\mathrm{D}($ INTR,2) & 94.94470 & 155.7686 & 0.609524 & 0.5513 \\
\hline $\mathrm{D}($ INTR(-1),2) & -2.486702 & 139.1761 & -0.017867 & 0.9860 \\
\hline ECM (-1) & -0.371992 & 0.135880 & -2.737646 & 0.0153 \\
\hline
\end{tabular}

Source: Author's computation (2021).

$\mathbf{R}^{2}=0.746973, \quad \mathrm{DW}^{*}=1.808991$

The results of the over-parameterized ECM reveals that the ECM term coefficient is critical with the negative sign. The coefficient value of ECM is -0.371992 , revealing that, the rate of adjustment to future equilibrium is $37.1 \%$ when any past deviation 


\section{The Relationship between Stock Market Development and the Performance of the Nigerian Economy}

are going to be corrected within the present period. This means that this value of LGDP changes gradually to vicissitudes in LMCAP, LFDI, LINFR, and LINFR.

Table 4: Results of Standard Error Test

\begin{tabular}{|l|l|l|l|l|}
\hline Variable & Co-efficient & Co-efficient/2 & $\begin{array}{l}\text { Standard Error } \\
\text { Statistics }\end{array}$ & Decision \\
\hline LMCAP & -14.15558 & 7.07779 & 1.83505 & Significant \\
\hline LFDI & 0.001551 & 0.0007755 & 0.00022 & Significant \\
\hline LINFR & 1523.462 & 761.7231 & 1523.462 & Significant \\
\hline LINTR & -1820.241 & 910.1205 & 956.839 & Insignificant \\
\hline
\end{tabular}

Source: Author's (2021).

Based on the above table, it can be inferred that most of the variables involved in the model are significant except LINTR in explanation of all the changes that happened in the value of LGDP.

\section{SUMMARY OF FINDING}

This research work is in a bid to critically examine and supply a big contribution to the recently increasing talks about the influence of exchange on the economic process. All statistical tests, on the long run were carefully evaluated with their various outcomes determined freed from any permutation respectively. In addition, causal relationship was established between Gross domestic product and three explanatory variables with the exception of market capitalisation (LMCAP) so as to supply a benchmark for the formulation of effective and efficient policy recommendations. Consequently, the parameters were individually evaluated and tested to ascertain their individual stationarity and their speed of adjustment to changes over time. The co-integrating equation was never unnoticed. The Johansen co-integration test which was adopted revealed two co-integrating equation. This signifies the flexibility of Gross domestic product to regulate to changes efficiently within the long run. Also, the speed of adjustment within the over-parametized Error Correction model and along side the Parsimonious Error Correction model showed an awfully slow rate response of Gross domestic product to any past changes. Meanwhile, the analysis did not fail within the establishment of the variables that causes the changes that occur in Gross domestic product using the Granger Causality test. The test revealed that Foreign direct investment (LFDI), rate (LINFR) and rate of interest (LINTR) are major causes of any changes in Gross domestic product while the effect of those changes now result a consequent explanation for changes within the other variables identified. This therefore indicates that changes in market capitalisation (LMCAP) caused by Gross domestic product (LGDP) with the unilateral relationship shown within the Granger Causality result.

\section{CONCLUSION/RECOMMENDATION}

The study shows that all variables may not have been a cause of change in Gross domestic product level, but this does not mean that there is no relationship between them and the explained variable. The variables that are not in accordance with the Apriori statement about their outcomes, but then it emphasizes the fact that study was done with extreme objectivity and also that care needs to be taken in macroeconomic decisions in order to avoid a divastating trade-offs. Meanwhile, this study has been done in it best possible and objective manner to serve as good starting point for further researcher and academicians who vows for a future development in the subject matter through objective contribution of this nature. The study therefore charge the monetary authority headed by the central bank of Nigeria (CBN) to put necessary plan in place and implement policies that will bring about an increase flow of investment funds and improves the extent of capitalisation to the Nigerian economy for better performance.

\section{REFERENCES}

1) Abdul, R. (2008). Macroeconomic Variables and Stock Exchange Performance. International institute of Islamic economics, 2 (6), 9-37.

2) Beck, T., \& Levine, R., (2002). Stock Markets, Banks and Growth: Panel Evidence". NBER Working Paper 9082.

3) Bernardo, R. (2005). Developing the Philippine capital market". [Web log post] Retrieved from http://romeobernardo.blogspot.com/2005/08/developing-philippine-capital-market.htmlBusiness Day Newspaper, February 19, 2009.

4) Donwa, P. \& Odia, J. (2010). An empirical analysis of the impact of the Nigerian Capital Market on her socio-economic development. Journal of Social Science, 24 (2), 135-142. 


\section{The Relationship between Stock Market Development and the Performance of the Nigerian Economy}

5) Ewah, S. O. E., Esang, A. E. \& Bassey J. U. (2009). Appraisal of Capital Market Efficiency on Economic Growth in Nigeria. International Business and Management. Lagos: Zeal Press.

6) Ekundayo, I.K. (2002). Creating Conducive Environment for Investment in Nigerian Capital Market". Paper Presented at Public Enlightenment on opportunities in the Capital Market for Industrial Development of Kogi State Lokoja 29th March to 1st April, 2002.

7) Mbat, D. O. (2002) Financial Management". Domes Associates Publishers. Uyo, Nigeria First Edition.

8) Ossisanwo, B. G. \& Atanda, A. A. (2012). Determinants of Stock Market Returns in Nigeria: A Time Series Analysis. African Journal of Scientific Research, 9(1),479-489.

9) Osaze, B.E. (2000). The Nigeria Capital Market in the African and Global Financial System. Benin City: Bofic Consults Group Limited.

10) Ogboi, C., \& Oladipo, S. O. (2012). Stock Market and Economic Growth: The Nigerian Experience. Research Journal of Finance and Accounting, 3 (4), 46-53.

11) Ramin, C. M., Lee, C. H., \& Mohamad, A. H (2004). Relationship between macroeconomic variables and stock market indices". Cointegration evidence from stock exchange of Singapores All- S Sector indices, Journal Penguran, 24, 47-77.

12) Rosseau, P. L., \& Watchel, P. (2000). Equity Markets and Growth: Cross-Country Evidence on Timing and Outcomes 19801995. Journal of Banking and Finance, 24, 1933-1957.

13) Ross, S. A. (1976)"The Arbitrage Theory of Capital Asset Pricing. Journal of Economic Theory, 13 (3), 341-360.

14) Soyode, A. (2009). Nigerian capital market and macroeconomic variables: an empirical analysis. Nigerian journal of monetary economics, 6, 10-15.

15) Sulaiman, D. M., Adnan, H., \& Adnan, A. (2009). The impact of macroeconomic variables on stock prices: Empirical evidence in case of KSE. European journal of scientific research, 38(1), 96-103.

16) Sulaiman, U.M., \& Mohammed,I. (2014). Stock Market Development, Foreign Direct Investment and Macroeconomic Stability: Evidence from Nigeria. Research Journal of Finance and Accounting, 5(18),258-264.

17) Yui, X.G. (2008). The efficiency of the Chinese stock market with respect to monetary policy. School of economics \& management journal, 2, (1), 45-53. 